\title{
CONTRIBUTIONS TO THE KNOWLEDGE OF FLORA AND VEGETATION OF THE TERTIARY IN THE EXTRACARPATHIAN AREA OF ROMANIA
}

\section{RĂZVAN GIVULESCU ${ }^{1}$}

\begin{abstract}
The author presents the fossil flora and vegetation of the extracarpathian regions of Romania: on one hand, the Eocene-Oligocene-Late Dacian fossil floras from the southern area, and on the other hand - the Sarmatian ones from the eastern area. It is insisted on the Sarmatian as compared to the one from Transylvania. There are important similarities with the southern area, but none as concerns the eastern one. The characteristic feature of the area comprised between the Carpathians and the Prut is the absence of the Lauraceae and the massive presence of Betulaceae. The author suggests the creation of a palaeofitogeographic and palaeoclimatic subprovince called Moldavica.
\end{abstract}

KEYWORDS: fossil flora, vegetation, Tertiary, Romania

\section{INTRODUCTION}

In 1997, on the occasion of publishing the monograph "The History of Fossil Forests in Transylvanian Tertiary" we were arguing this apparent regionalism with the fact that as compared to the 54 fossil floras which can be cited for Transylvania, Banat, Crişana, and Maramureş, in the extracarpathian regions, south or east of the Carpathians, the floristic inventory is incomparably poorer, whether we refer to the fossiliferous points, or to their inventory. This was the reason why we gave up their presentation at that moment. Yet we consider that the fossil flora of Romania cannot be conceived without the study of these floras, inasmuch we know them. We cannot speak about a whole, without also presenting the extracarpathian floras. They will make the object of the this study, in which we will present the fossil floras of the Tertiary from Oltenia, Muntenia and Moldova, or, for simplicity:

I. The tertiary fossil floras from the area between the Carpathians and the Danube.

II. The tertiary fossil floras from the area between the Carpathians and the Prut.

We owe the knowledge of these floras either to more recent studies Țicleanu, Stancu and Țicleanu, or to older ones - Barbu 1954.

In both situations, nomenclatoric or even taxonomic interventions were required, to bring the studies up to date. In the first mentioned area, the following floras were described:

a. Late Eocene - Oligocene: Muereasca de Sus, Suslăneşti

b. Badenian: Ciocadia and Pârlagele

c. Sarmatian: Slătioara, Pietrarii de Sus, Tănăşeşti-Râmeşti, Porceni, Râmeşti

d. Late Pontian - late Dacian: Cărbuneşti, Temişani, Dedovița.

\footnotetext{
17 Donath str., ap.66, Cluj-Napoca, România.
} 


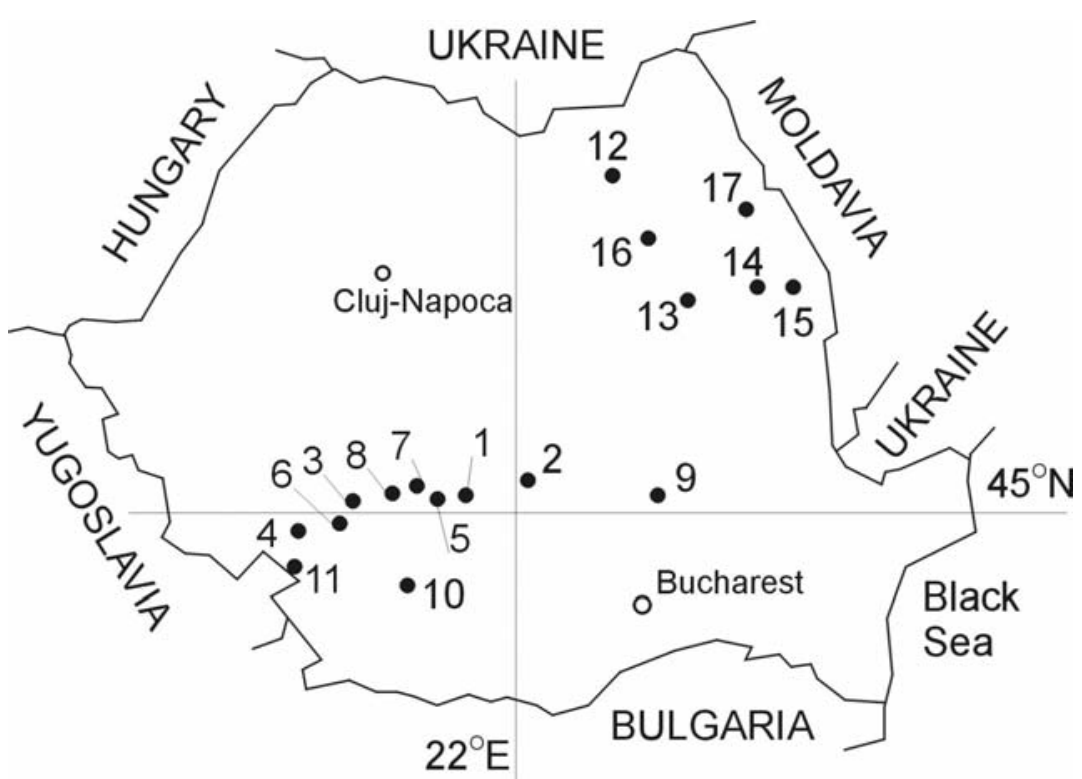

Fig. 1. Location of sites on the map of Romania. 1 - Muereasca de Sus; 2 - Suslăneşti; 3 - Ciocadia; 4 - Pârlagele; 5 - Slătioara; 6 - Porceni; 7 - Râmeşti; 8 - Tănăseşti-Râmeşti; 9 - Cărbuneşti; 10 - Temişani; 11 - Dedovița; 12 - Fălticeni; 13 - Comăneşti; 14 - Hârşova; 15 - Buneşti; 16 - Corni; 17 - Păun/laşi

\section{DESCRIPTION OF THE FLORAS} the Danube

I. The tertiary fossil floras from the area between the Carpathians and

\section{a. The Late Eocene - Oligocene floras}

\section{a.1. The fossil flora from Muereasca de Sus.}

Muereasca de Sus is located north of Râmnicu-Vâlcea, on the Muereasca brook, right affluent of the Olt River. As concerns the fossiliferous site, it was discovered, after Barbu (1936), on the same brook, in the place called Capul lazului. The plants have been collected from marls, which appear as insertions in a succession of gritstone marls. The succession lacks fossils, therefore its age is appreciated only in the general geological frame, as Late Eocene - Early Oligocene. The flora was the object of study for Marion and Laurent (1895), and later for Barbu (1936) who published the first extensive study of it. It was revised by Givulescu in 1992, but only on the basis of Barbu's work. This revision emphasized the following list of plants:

cf. Amentotaxus gladiifolia (Ludwig) Ferg., Jähn., Alvin

Doliostrobus taxiformis (Mar.) Kv.

Coniferae sp. conus

Salix varians Goepp. 


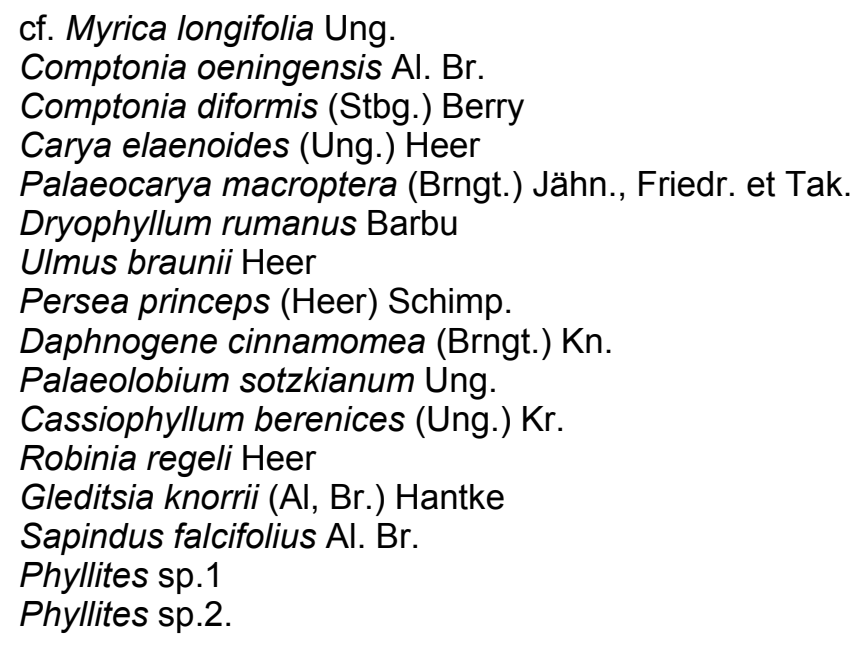

The presence, firstly, of Doliostrobus and Dryophyllum, but also of Palaeolobium, Daphnogene cinnamomea, and possibly Myrica longifolia, confers to this flora the unquestionable feature of an old Tertiary one, ante Chattian. As it appears, this small flora of only 19 taxa (18 genera and 11 families) gives the impression of a mixture, an accidental tafocenosis with elements originating from different palaeoenvironments, a mixture of arctotertiary and palaeotropical types, represented by trees and shrubs, some with entire, others with dentate leaves. Statistics is out of question, due to the reduced number of taxa. We consider that this material was brought by water (except for the Palaeocarya and UImus) into a sea deposit where it was scattered by waves. Its satisfactory state of preservation indicates a short-term transportation.

\section{a.2. The fossil flora from Suslăneşti}

Suslăneşti village is located in the proximity of the city Câmpulung-Muscel. The fossiliferous sites are situated to the north of the village, in Mărlăuz dale, but also in Malul Mătuşei, Crângu or Dealul Curcanilor. There is a succession of menilitic and disodilic shales rich in fossil fish skeletons, fish scales and plants (Paucă 1933). Their age is estiomated, without any other details, as Oligocene. Yet we remind that Paucă considered them to be Rupelian, on basis of Clupea crenata $=$ C. Iongimana. Besides Paucă (1933), the plants have been studied at length by Givulescu (1989 and 1989a). The vegetal material appears at the surface of disodilic shales plates as impressions, exceptionally compressions, and is generally well preserved. It is a somewhat richer tafocenosis, containing 20 taxa. It's worth to be mentioned that we are considering it as a dispersed plant deposit - they do not appear in a single point and at a single level, but are spread in the whole package of shales, which shows irregular and quite accidental contributions of fossil material. Anyway, their transportation was not a long-term one and then they sedimented quietly, being covered with silt. What raises questions is the fact that in these unquestionably non-oxygenated waters the plants were still preserved as impressions and not compressions, which would have been normal in an anoxic environment. 
We present a list of the identified plants, with the mention that it could have been much more comprehensive if the material would not have been covered with a non-transparent varnish.

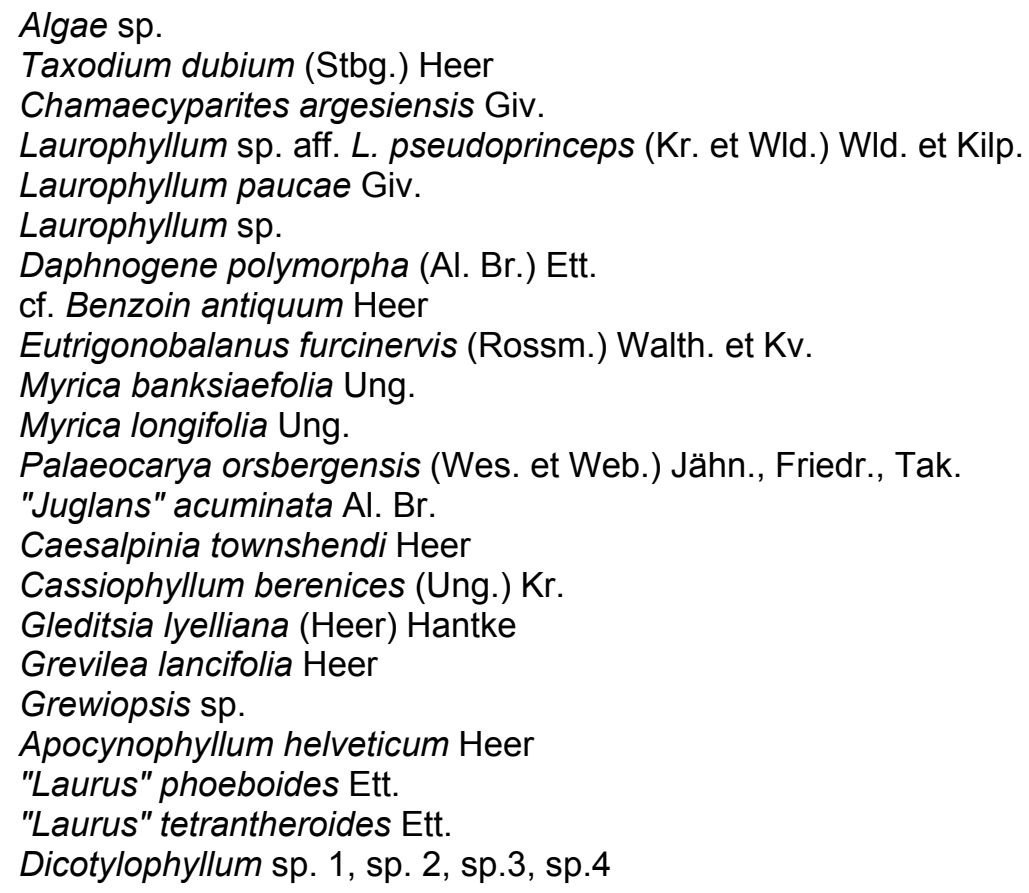

The examination of this list, in fact very modest, shows mainly an essential fact: the disappearance of Doliostrobus and its replacement by Taxodium, which suggests, as we think, that we are dealing with a younger level of the Oligocene than that from Muereasca de Sus. There are also many Lauraceae and Leguminosae. We will add to the list as typical Oligocene Eutrigonobalanus, Apocynophyllum, the two types of Myrica and the long-lived Palaeocarya orsbergensis, which attains maximum development during this time lag. Considered on the whole, the flora has an unquestionable Oligocene appearance, as it is also found at Corneşti/Aghireş near Cluj-Napoca. As concerns the frequency we will remind that the material appears in singular samples except for Eutrigonobalanus (7) and Myrica (11). Finally we will underline the great number of algae, which, although unidentified, show quiet nearshore waters. We must imagine the vegetation of Oligocene period from Suslăneşti (and, of course, not only from here) as coming from at least two palaeobiotops: one of a river meadow with Gleditsia, Daphnogene, Palaeocarya, Eutrigonobalanus, and another one of hillock regions with Apocynophyllum, Lauracee, Myricacee, Juglans, Cassiophyllum, Caesalpinia, all these forming more or less bound associations of trees and shrubs. There is also Taxodium, which might have vegetated close to running water, very probably as isolated specimens. It is impossible to accept a description like "swamp areas", as Paucă (1933) asserts.

Although the number of identified taxa of this flora is relatively reduced, we have still tried, for curiosity, to establish the proportion entire leaves versus dentate 8 
leaves. The result was improbable (84:16\%), especially if we compare it with what we know about the flora from Corneşti, accomplished on basis of a very large number of fossil leaves: $57,57 \%$ : $42,42 \%$. If the first result refers to a subtropical wet or even rainy climate, the second one refers also to a very wet climate, but of a temperate warm type. Is it acceptable that on the two sides of the Carpathians, still to appear, had existed two such distinct climates? Our answer is definitely negative, for our opinion is that there had been a more or less similar climate on the whole territory, more exactly the Oligocene dry land, and it is the one from Corneşti.

\section{b. The Late Badenian flora}

This flora comes from two localities: Ciocadia from Gorj and Pârlagele from Mehedinți. But since both fossiliferous sites, although remote, appear at the same stratigraphic level of the Badenian, namely the one with Velapertina iorgulescui which indicates a Late Badenian, we will study them together.

Ciocadia is situated in the westside of Gorj county. Țicleanu (1984), who studied the flora, gives no detail about the site of collection. Pârlagele locality, on the other hand, is situated $12 \mathrm{~km}$ northeast of Drobeta Turnu Severin. Here, the plants appear in the middle part of Negoiasa valley and of some tributaries in several points (Stancu and Țicleanu, 1975). The plants appear here as impressions covered with a coal film, they are rather fragmented and some of them even contorted. Obviously, it was an occasional transport by running waters, in other words a diffuse deposit type. In this case we cannot, practically, speak of a tafocenosis.

Unlike it, the plants from Ciocadia appear in the form of a fossiliferrous site. The material is generally satisfactorily preserved, as impressions. The large quantity of Pinus keys and seeds prove an active air transport, along with one by running water, which had not deteriorated too much or even at all the leaves in question. Taking into account that this is the flora of the same stratigraphic level, we will present the flora together and not by separate points.

Late Badenian flora contains 32 taxa, and it allows some statistic conclusions to be drawn. It contains 20 genera (one "incertae" and 12 families), so it is a varied flora. The ratio entire leaves:dentate leaves is of $33,33 \%: 66,66 \%$, the ratio arctotertiary:palaeotropical is of $64,70 \%: 35,29 \%$, numbers which seem normal for this time-lag. The change of flora composition in Miocene concerning the dentate leaves as well as the arctotertiary element is obvious. From the point of view of the flora, it is a normal Middle Miocene one, with many Pinus, Tetraclinis in its first extracarpathian occurence, Trigonobalanopsis rhamnoides in the same first occurence, Palaeocarya, with not too many Lauraceae, but rich in Aceraceae. We must underline the appearance of Castanea kubinyi, the typical Sarmatian taxon. This kind of palaeocenosis had unquestionably vegetated in different palaeoenvironments. The most important of them seems to have been the one of dry hillock land, of different exposition, with Betula, Carpinus, Juglans, Ulmus, Tilia, Acer, Persea, Trigonobalanopsis, and, obviously, Castanea. Many remains had been brought by the wind from different distances. Another palaeobiotop is the river meadow one with Palaeocarya, Daphnogene, Gleditsia. There might have been more marshy, wet places in this area, where, probably, Tetraclinis, Myrica, Populus had vegetated. The numerous Pinus had probably vegetated in all palaeoenvironments. 
Summary of Badenian flora

\begin{tabular}{|c|c|c|c|}
\hline Name of the taxon & Locality & Climate & $\begin{array}{l}\text { Leaf } \\
\text { type }\end{array}$ \\
\hline Acer cf. platanoides L. & & C - key & \\
\hline Acer sp. aff. angustilobum Heer & $\mathrm{P}$ & $A$ & $\mathrm{D}$ \\
\hline Acer sp. key & C & & \\
\hline Acer tricuspidatum Bronn & $\mathrm{C}, \mathrm{P}$ & A & $\mathrm{D}$ \\
\hline Betula sp. aff. macrophylla (Brngt.) Heer & C & A & $\mathrm{D}$ \\
\hline Carpinus sp. ex gr. betulus L. & & C - bractea & \\
\hline Carpinus sp. ex gr. caroliniana Walt. & & C - bractea & \\
\hline Carpinus sp. ex gr. kisseri Berger & & C - bractea & \\
\hline Castanea kubinyi Kov. ex Err. & C & A & $\mathrm{D}$ \\
\hline Carya sp. & $\mathrm{C}$ & A & $\mathrm{D}$ \\
\hline Daphnogene polymorpha (Al.Br.) Ett. & $\mathrm{C}, \mathrm{P}$ & $\mathrm{P}$ & $\mathrm{E}$ \\
\hline Gleditsia aquatica (Heer) Mai & $\mathrm{C}$ & $A$ & $\mathrm{D}$ \\
\hline Gleditsia lyelliana (Heer) Hantke & C & A & $\mathrm{D}$ \\
\hline Juglans acuminata Al. Br. & $\mathrm{P}, \mathrm{C}$ & A & $\mathrm{E}$ \\
\hline Myrica lignitum (Ung.) Sap. & $\mathrm{P}$ & $\mathrm{P}$ & $\mathrm{D}$ \\
\hline $\begin{array}{l}\text { Palaeocarya orsbergensis Wess et Web, Jähn., } \\
\text { Fridr. }\end{array}$ & $\mathrm{C}, \mathrm{P}$ & $\mathrm{P}$ & $\mathrm{D}$ \\
\hline Persea givulescui Ticl. & $\mathrm{P}$ & $\mathrm{P}$ & $\mathrm{E}$ \\
\hline Persea princeps (Heer) Schimp & C & $\mathrm{P}$ & $\mathrm{E}$ \\
\hline Phyllites sp. & $\mathrm{C}, \mathrm{P}$ & & $E$ \\
\hline Phyllites sp. aff. Leguminosites sp. & $\mathrm{C}$ & & $E$ \\
\hline Pinus cf. halepensis Mill. & $\mathrm{C}$ & A & \\
\hline Pinus laricoides Menzel & $\mathrm{P}$ & A & \\
\hline Pinus maritima Poir. & $\mathrm{C}$ & A & \\
\hline Pinus sp. semina tip 1 & $\mathrm{P}$ & & \\
\hline Pinus sp. semina tip 2 & $\mathrm{P}$ & & \\
\hline Populus sp. (an n. sp.?) & $\mathrm{P}$ & A & $\mathrm{D}$ \\
\hline Ramulus pini & $\mathrm{P}$ & & \\
\hline Tetraclinis salicornioides (Ung) Kv. & $\mathrm{C}$ & $\mathrm{P}$ & \\
\hline Tilia josephinae Ticl. & $P$ & A & $\mathrm{D}$ \\
\hline $\begin{array}{l}\text { Trigonobalanopsis rhamnoides (Rossm.) Walt. et } \\
\text { Kv. }\end{array}$ & $\mathrm{C}, \mathrm{P}$ & $\mathrm{P}$ & $\mathrm{E}$ \\
\hline Ulmus brauni Goepp. & C & A & $\mathrm{D}$ \\
\hline Ulmus pyramidalis Goepp. & $\mathrm{P}$ & A & $\mathrm{D}$ \\
\hline
\end{tabular}

Locality: C - Ciocadia, P - Pîrlagele; Climatic feature: A - arctotertiary, P - palaeotropical; leaf type: $E$ - entire, $D$ - dentate.

Although the material is quite scarce, we tried to build a histogram of leaf size classes. The result is the following:

$\begin{array}{ll}\text { nanophill } & 21,42 \% \\ \text { microphyll } & 60,71 \% \\ \text { notophyll } & 14,28 \% \\ \text { mesophyll } & 3,75 \%\end{array}$




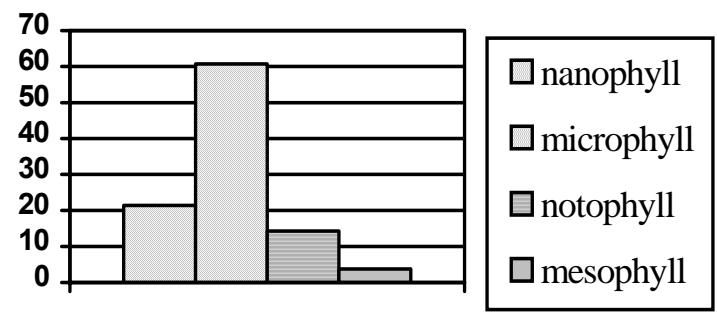

Fig. 2. Leaf size histogram. Badenian flora.

Two facts become obvious: the predominance of the microphyll class, yet in normal limits, and the existence of four size classes. It is a well-balanced histogram from the category of credible.

\section{c. The Sarmatian flora}

The richest flora of the discussed perimeter is the one belonging to the Sarmatian. This flora is located exclusively in Oltenia. It belongs to Early Sarmatian (Slătioara), Late Bessarabian (Porceni, Râmeşti) and Bessarabian-Kersonian (Tănăseşti-Râmeşti). The richest and the most representative of them is the one from Slătioara with 25 taxa. All the others contain less than 20 taxa. Concerning the age: the flora from Slătioara integrates into the biozone with Cystosteirites partschi, a fossil specific for the Early Sarmatian in the whole Pannonian area. The floras from Porceni, as well as the one from Râmeşti, are dated not according to the fossils, but by their stratigraphic position; finally, the flora from Tănăşeşti-Râmeşti is dated by the presence of Cryptomacra pesanseris and Mactra bulgarica as belonging to the Bessarabian-Kersonian.

Taking into account the fact that we are dealing with a well-defined stratigrafic interval, in which the fossil floras present only small unimportant variations, we considered possible to study them altogether. It must also be specified that the whole material is preserved as impressions, the best preserved being those from Porceni, while the others often present broken, incomplete leaves. The material is unquestionably allochtonous in all the points mentioned, being brought by the wind (Pinus, Acer, Palaeocarya), and by running waters. The presence of Cystoseirites alga at Slătioara indicates quiet waters, near the shore. With 12, 15 and 17 specimens we cannot talk but about absolutely accidental tafocenoses. We must also specify that Barbu (1956) mentioned at Porceni a Doliostrobus sternbergi, which does not belong to a Miocene flora. We think it might possibly be a Cryptomeria. Ilex sturdzai Marion et Laurent was also not taken into consideration. The leaf mentioned by the authors was not described anywhere. Finally, we grouped the great number of Pinus seeds, assigned to numerous present-day types described at Porceni, into Pinus sp.-semina. A close look at the flora shows the presence of several conifers: Glyptostrobus (only at Râmeşti), Pseudotsuga, Tetraclinis, and especially the numerous remains of Pinus - needles and winged seeds. The Lauraceae are weakly represented: only Daphnogene (in three sites), Sassafras and Laurophyllum (also in three sites), while the Juglandaceae appear by Juglans, Carya, Pterocarya, but 
RĂZVAN GIVULESCU

Tab. 2.

The fossil flora of the Sarmatian in Oltenia

\begin{tabular}{|c|c|c|c|}
\hline Name of the taxon & Locality & Climate & $\begin{array}{l}\text { Leaf } \\
\text { type }\end{array}$ \\
\hline Acer tricuspidatum Bronn & Sl & A & D \\
\hline Acer sanctae crucis Stur & SI & A & D \\
\hline Acer platanoides $\mathrm{L}$. & $\mathrm{P}$ & A & D \\
\hline Acer pseudoplatanus L. & $\mathrm{P}$ & A & D \\
\hline Andromeda protogaea Unger & SI & $P$ & $E$ \\
\hline Anona eliptica Unger & SI & $P$ & $\bar{E}$ \\
\hline Betula dryadum Sap. & $\mathrm{SI}, \mathrm{P}$ & A & $\bar{D}$ \\
\hline Carpinus cf. grandis Ung. & T-R & A & D \\
\hline Carpinus orientalis Mill. & $\mathrm{SI}, \mathrm{P}$ & $A$ & $\mathrm{D}$ \\
\hline Carya serraefolia (Goepp.) Kr. & $\mathrm{P}$ & A & D \\
\hline Cassiophyllum berenices (Ung.) Kr. & SI & $\mathrm{P}$ & $\mathrm{E}$ \\
\hline Castanea kubinyi Kov. ex Ett & SI, P, R & A & $\overline{\mathrm{D}}$ \\
\hline Colutea salteri Heer & SI, T-R & A & $E$ \\
\hline Cystoseirites partschi Stbg. & SI & & \\
\hline Daphnogene polymorpha (Al.Br.) Ett & $\mathrm{SI}, \mathrm{R}, \mathrm{T}-\mathrm{R}$ & $\mathrm{P}$ & $\mathrm{E}$ \\
\hline Fagus silesiaca Walt. et Zast. & SI, P & A & D \\
\hline Fraxinus sp. & SI, R, T-R & A & $\mathrm{D}$ \\
\hline Glyptostrobus europaeus (Brngt) Ung. & $\mathrm{R}$ & A & \\
\hline Juglans acuminata Al.Br. & $\mathrm{R}, \mathrm{T}-\mathrm{R}$ & A & $\mathrm{E}$ \\
\hline Laurophyllum brauni (Heer) Nem. et Kn. & SI, R, T-R & $P$ & $\mathrm{E}$ \\
\hline Liriodendron procaccini Ung. & $\mathrm{P}$ & A & $\overline{\mathrm{D}}$ \\
\hline Leguminosites sp. & $P, R$ & $A / P$ & $\mathrm{E}$ \\
\hline Nerium sp, aff, $N$. oleander $\mathrm{L}$. & $\mathrm{T}-\mathrm{R}$ & $\mathrm{P}$ & $\bar{E}$ \\
\hline $\begin{array}{l}\text { Palaeocarya orsbergensis (Wess. et Web.) Jähn. } \\
\text { Friedr. }\end{array}$ & $\begin{array}{l}\text { SI, R, } \\
\text { T-R }\end{array}$ & $P$ & $\mathrm{D}$ \\
\hline Palaeocarya maxeoptera (Brngt.) Jähn., Friedr - Tak. & $\mathrm{P}$ & & \\
\hline Periploca cf. graeca L. & SI & A & $E$ \\
\hline Phragmites oeningensis $\mathrm{Al}$. $\mathrm{Br}$. & T-R & A & \\
\hline Pinus sp. - binae & $P, T-R$ & A & \\
\hline Pinus maritima Poir & $\mathrm{SI}$ & A & \\
\hline Pinus leptophylla Sap. & SI & A & \\
\hline Populus populina (Brngt.) Kn. & $\mathrm{P}$ & $A$ & D \\
\hline Pseudotsuga aff. douglasi Carr. & SI & A & \\
\hline Pterocarya cf. caucasica Spach & $R, T-R$ & A & D \\
\hline Quercus neriifolia Heer & SI & $A$ & $\mathrm{E}$ \\
\hline Robinia affinis Heer & $\mathrm{P}$ & A & $\bar{E}$ \\
\hline Salix longa Heer & $\mathrm{R}, \mathrm{T}-\mathrm{R}$ & $A$ & $E$ \\
\hline Salix varians Goepp. & $\mathrm{R}, \mathrm{T}-\mathrm{R}$ & A & D \\
\hline Sapindus falcifolius Al. Br. & SI, T-R & $\mathrm{P}$ & $\mathrm{E}$ \\
\hline Sassafras sp. & $T-R$ & A & $\bar{D}$ \\
\hline Tetraclinis salicornioides (Ung. Kv.) & $\mathrm{T}-\mathrm{R}$ & $A$ & \\
\hline Tilia sp. & SI & A & D \\
\hline Ulmus pyramidalis Goepp & SI, T-R & A & $\mathrm{D}$ \\
\hline Zelkova zelkovaefolia (Ung.) Buz. et Kn. & SI, T-R & $A$ & $\mathrm{D}$ \\
\hline
\end{tabular}

Locality: SI - Slătioara, P - Porceni, R - Râmeşti, T-R - Tănăseşti-Râmeşti; Climatic feature: A - arctotertiary, P - palaeotropical; leaf type: D - dentate, E - entire. 
especially by Palaeocarya (leaves and bracteae). From Fagaceae we mention some remains of Fagus, which appears in Transylvania only much later, then Castanea and Quercus neriifolia, but not Quercus dentate or lobed. Different types of Acer, among which $A$. tricuspidatum, represent the Aceraceae then we mention also the Salicaceae, Fabaceae with Cassiophyllum Robinia and Colutea and the Betulaceae weakly represented only by bracteae. Yet it is worth mentioning the presence of some rarities: Liriodendron proccacini (bracteae), Nerium cf. oleander, Anona eliptica, Periploca cf. graeca and a bractea of Tilia.

The flora from Slătioara belongs to the floras with Cystoseirites and Palaeocarya from Transylvania. The connections between Oltenia and Transylvania during the Early Sarmatian seem to have been total from the point of view of vegetation. In fact, if we compare the flora from Slătioara with those described in Transilvania from the point of view of the parameters entire leaves:dentate leaves, we will find that it is most similar to the one from Deva-Tâmpa (Givulescu 1992, Givulescu-Barbu 1997).

From the point of view of palaeovegetation we will first distinguish the one of hillock areas of different altitudes, expositions, palaeoenvironments, an association of mesophytic forest. On the other hand: Daphnogene, Palaeocarya, Acer tricuspidatum, Salix, Zelkova and Pterocarya indicate a river meadow or alluvial area environment, more or less wet. Our conclusion is that we are dealing with a mixed mesophytic flora type, the representative of a wet warm temperate vegetation, which shows strong affinities with the present-day floras from Transylvania.

At the end, the last problem: we had the curiosity to compose a histogram of the leaf size classes on the basis of the entire Sarmatian leaf material. It presents as follows:

$\begin{array}{ll}\text { nanophyll } & 8,38 \% \\ \text { microphyll } & 77,08 \% \\ \text { notophyll } & 12,50 \% \\ \text { mesophyll } & 2,08 \%\end{array}$

Fig. 3. Leaf size histogram. Sarmatian flora.

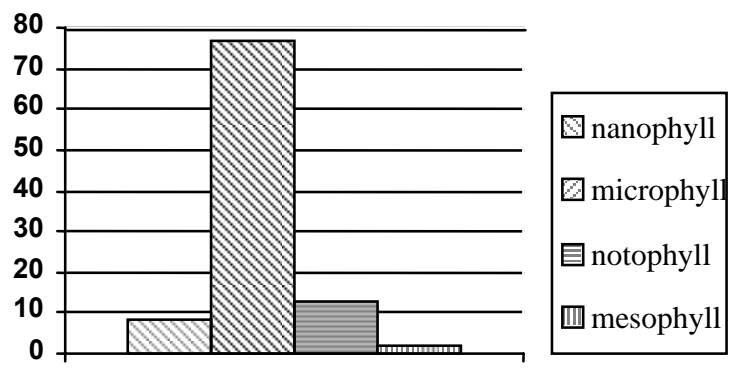

The histogram belongs to the category of improbable, due to the high percentage of microphyll. 


\section{d. The fossil flora of Late Pontian - Late Dacian period}

\section{d.1. Late Pontian - Early Dacian flora from Cărbuneşti.}

This locality is situated in the north-east side of Prahova county. The fossil plants have been collected from two sites: Soreasca and Rogoatele brooks. In the first case, from sandy marls or reddish marls with Pachydacna serena, P. cobălcescui and Prosodacna rumana; in the second case, also from a sandy-marl succession, but with Prosodacna haueri haueri, Viviparus rumanus and Stylodacna heberti. So, in the first case, the deposits belong to the Late Pontian, and in the second case they belong to the Early Dacian. The list of plants collected in these two fossiliferous sites is more than modest: only 14 taxa. There are two deposits of the diffuse type, an absolutely accidental tafocenosis transported and especially selected by waters. The whole material appears in the form of impressions. The list of the revised material is the following:

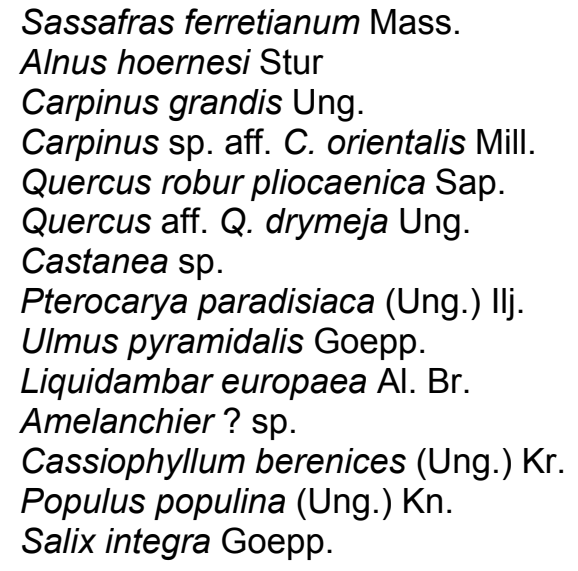

This small flora, a simple accidental accumulation, still shows some peculiar characteristics, which must be pointed out. Among the presences we will underline, the first appearance of the types of roburoid Quercus. Then the presence of the lauraceae Sassafras, mentioned until now only at Chiuzbaia, and of Alnus hoernesi, a rarity even in the rich floras from Transylvania. Pterocarya paradisiaca and Liquidambar europaea are also new for this geographic area. We will also underline the absence (accidental, probably) of Pinus types so well represented in the floras of the Sarmatian, the absence of ferns, of Betula, Zelkova and others. But we underline that it is an excerpt of flora. As concerns the vegetation we can say just the following: mesophytic hillock vegetation, not yet differentiated from the Sarmatian.

\section{d.2. The Dacian flora from Temişani}

The locality is situated in the south-west of Gorj county, on the right bank of Jiu river and on the homonym brook. However, the fossil plants have been collected from the Halingi valley, Stana and Brazi, especially from a succession of red ripe clays. The flora described by Barbu (1933) is small: it contains only 15 taxa, being a diffuse tafocenosis, an accidental accumulation that mixed up the plants of two biocenoses. The material identified and, especially, revised contains: 


\section{CONTRIBUTIONS TO THE KNOWLEDGE OF FLORA AND VEGETATION OF THE TERTIARY ...}

Osmunda regalis L, var. fossilis Barbu

Glyptostrobus europaeus (Brngt.) Ung.

Parrotia pristina (Ett.) Stur

Pterocarya paradisiaca (Ung.) Ilj.

Sapindus falcifolius Al. Br.

Buxus sempervirens L. fossilis Engelh.

Populus populina (Brngt.) Kn.

Salix stefănescui Mar. et Laur.

Salix varians Goepp.

Salix pliocaenica Barbu

Salix sp. aff. S. babylonica L.

Salix fragilis L. fossilis Barbu

Byttneriophyllum tiliaefolium (Al.Br.) Kn. et Kv.

Phyllites sp.1

Phyllites sp.2

This flora shows no special features, except for the presence of Pteocarya, Sapindus, and especially Buxus, one of the rare specimens of Buxus cited in Romania (see Givulescu, 1971). Surprising is the presence of no less than 5 species of Salix which, as it seems, must be accepted as they are. For the first time there appears a fern - Osmunda. Also for the first time, Byttneriophyllum is cited.

As concerns the vegetation, we are dealing unquestionably, at least partially, with a vegetation of carbogenerator facies: Glyptostrobus and Byttneriophyllum, to which Osmunda is added. From more damp, aluvial areas come the Saliaceae, Pterocarya, possibly Populus. From the dry land of the surroundings - Sapindus, Buxus, Parrotia, all of solar exposition. They represent only a modest sample of a vegetation from the dry surroundings.

\section{d.3. Late Dacian flora from Dedovița}

The locality is situated in the vicinity of Drobeta Turnu Severin town. The fossil plants have been collected, on one hand, from the springs of Dedovița Valley, on the other hand, from Poroina Valley, that is from blue and yellow compact marls, with Viviparus argesensis, Hyriopsis sp. and Unio sp., which date them as Late Dacian. The tafocenosis is very poor, obviously being a diffuse deposit, of plants brought accidentally by watercourses and sedimented in the Dacian lake.

They are obviously accidental accumulations. We will also remind that the plants appear as impressions. The list of identified plants is the following:

Pinus sp.

Sequoia abietina (Brngt.) Kn.

Glyptostrobus europaeus (Brngt.) Ung.

Alnus cf. gaudini (Heer) Kn. et Kv.

Alnus sp.

Betula cf. macrophylla (Goepp.) Heer

Carpinus grandis Ung. - folia, bractea

Fagus silesiaca (Goepp.) Walther et Zast.

Quercus cf. roburoides Bér. 
Carya serraefolia (Goepp.) Kr. Juglans acuminata Al. Br.

Salix integra Goepp.

Salix sp. aff. S. varians Al. Br.

Liquidambar europaea Al. Br.

From the beginning we will underline two facts: except for two types, all the others have a dentate edge, but the whole material is of arctotertiary type - a very significant fact. Unquestionably, the most interesting appearance is the presence of Sequoia abietina, a relict, but which appears under the same conditions also in Transilvania, at Chiuzbaia. The longevity of this taxon from the Early Tertiary is remarkable. Interesting is also the presence of a Quercus of the roburoid type, which, as in Transylvania at Borsec, Bodos and Biborțeni, appears as normal in the context of the Pliocene. The rest of the flora shows nothing special.

A simple look at the list of flora shows that it comes from two palaeobiotops, clear but unequally developed, at least judging by the frequency of the remains. We have, first, the one of the marshy forest, to which a river meadow one is added, that is with Glyptostrobus and Alnus on one hand, and Salix, possibly Carya, on another hand; second, we can speak of a mesophytic forest with Fagus, Quercus, Carpinus, then Juglans, Liquidambar and Betula. It is very probable that rare specimens of Sequoia had vegetated in this forest, in isolation, like at Chiuzbaia, as well as we might suppose that they had vegetated totally isolated in their favourite environment of acid peaty soil.

\section{The fossil flora of the area between the Carpathians and the Prut River}

This flora is characterized by:

- it belongs exclusively to the Sarmatian;

- it is poor - in fossiliferous sites (only 6) - as well as in what concerns their content. With one exception (Comăneşti - more or less autochtonous flora), the rest are accidental - allochtonous accumulations, in some tafocenoses the importance of which consists only in the fact that they suggest the existence of a vegetation of a certain type on the surrounding dry land.

From a stratigraphic point of view these floras can be grouped as follows: Early Sarmatian - Fălticeni, Middle Sarmatian (Bessarabian) - Hârsova, Bunesti, Corni, Late Bessarabian - Kersonian - Comănesti, Kersonian - Păun/laşi.

From the facies point of view they are of a marshy forest facies: Fălticeni and Comăneşti, the rest belong to mesophytic forests. We will consider them separately.

\section{a. The floras from Fălticeni and Comăneşti.}

If the first is an accumulation of only 6 vegetal remains, which are fortunately characteristic, the second contains 18 types, characteristic as well.

Leaving aside for the moment the allochtonous remains of the mesophytic forest, we find as types common for both floras: Osmunda (regalis or parschlugiana), Glyptostrobus and the types of Alnus: gaudini at Fălticeni, kefertseini latior, and especially cecropiaefolia - at Comăneşti. The characteristic element for an association 
CONTRIBUTIONS TO THE KNOWLEDGE OF FLORA AND VEGETATION OF THE TERTIARY ...

Tab. 3

Sarmatian flora (of carbogenerator type) from Comăneşti and Fălticeni

\begin{tabular}{lcc}
\hline Name of the taxon & Locality & Climate \\
\hline Acer ezoanum Oishi et Huz. & $\mathrm{C}$ & $\mathrm{A}$ \\
Acer sp. & $\mathrm{C}$ & $\mathrm{A}$ \\
Alnus cecropiaefolia (Ett.) Berger & $\mathrm{C}$ & $\mathrm{A}$ \\
Alnus kefersteini (Goepp.) Ung. & $\mathrm{C}$ & $\mathrm{A}$ \\
Alnus latior Sap. & $\mathrm{C}, \mathrm{F}$ & $\mathrm{A}$ \\
Betula oxydonta Sap. & $\mathrm{C}$ & $\mathrm{A}$ \\
Betula prisca Ett. & $\mathrm{C}$ & \\
Betula sp. & $\mathrm{C}$ & $\mathrm{P}$ \\
Byttneriophyllum tiliaefolium (Al. Br.) Kn. et Kv. & $\mathrm{C}, \mathrm{F}$ & $\mathrm{A}$ \\
Carpinus grandis Ung. & $\mathrm{C}$ & \\
Carpinus sp. & $\mathrm{F}$ & $\mathrm{A}$ \\
Corylus mac-quarrii (Forb.) Heer & $\mathrm{C}$ & $\mathrm{A}$ \\
Fagus silesiaca (Goepp.) Walt., Zast- & $\mathrm{C}, \mathrm{F}$ & $\mathrm{A}$ \\
Glyptostrobus europaeus (Brngt) Ung. & $\mathrm{F}$ & $\mathrm{A}$ \\
Osmunda cf. regalis L. & $\mathrm{C}$ & $\mathrm{A}$ \\
Osmunda parschlugiana (Ung.) Andr. & $\mathrm{C}$ & \\
Phragmites oeningensis Al. Br. & $\mathrm{C}$ & \\
Potamogeton sp. & $\mathrm{C}$ & \\
Pteris sp. & $\mathrm{C}$ & $\mathrm{A}$ \\
Salix varians Goepp. & & \\
\hline
\end{tabular}

Locality: C - Comăneşti, F - Fălticeni; Climatic feature: A - arctotertiary, P - palaeotropical.

from a marshy forest, and we refer to Byttneriophyllum which appears only at Comăneşti, is absent at Fălticeni. The problem is how we interpret this absence: it did not vegetate, or it did not get into the deposit? Taking into consideration that we are dealing with a tree that supplies impressive quantities of leaves, it is impossible for as small a remnant not to have fossilized. We must then admit that it had not vegetated, and the moment of its appearance not only in the flora of Moldova, but also in that of Romania, is the Bessarabian-Kersonian lag. In fact, at Comăneşti we find for the first time the triad: Glyptostrobus, Byttneriophyllum, Alnus cecropiaefolia. If we add some remains of Salix, we will have the full image of the marshy forest that will develop in the Paratethys area at the basis of Pontian, a forest that appears here for the first time. In the rest of the palaeoassociation we find almost the same elements brought from dry land: Coryllus, Betula, Carpinus, in addition a Fagus at Comăneşti, also here an Acer, elements of a mesophytic forest of higher altitude and a little colder. We will also remind that except for the Byttneriophyllum, the whole material is of arctotertiary type. Finally, concerning the carbogenesis, it seems that the marshy forest from Fălticeni was just an unsuccessful attempt to make such a facies, while the one from Comăneşti generated important coal deposits in the region. This was a well outlined and well-formed forest, where the tectonic factor, respectively the subsidence, also played an essential role in its promotion. 


\section{b. Mesophytic type flora of the Middle Sarmatian}

It contains a number of three floras: Hârşova ( 9 types), Buneşti (7 types) and Corni (12 types), in other words more than modest. Anyway, cumulatively, it offers us an image, even if fragmented, of the Sarmatian reality. A specific feature of these floras is the variety. Different families, genera, and species are present. The predominant genus is Carpinus - leaves and bracteae, then two types of Quercus, Zelkova, Ulmus. Rare and seldom appearing are Liquidambar, Fagus, Juglans, Corylus, Platanus, Populus, Fraxinus. Special mention must be made about the absence of the conifers, ferns, and especially of the important group of the Lauraceae from which only one is present, Laurus (Persea) princeps at Hârşova. It is a very significant fact if we compare it with the situation in Transylvania.

These plants are representatives of a mesophytic forest, of a generally equal exposition, a forest of a warm temperate climate. Some of them indicate a river meadow habitat - Salix, Populus, Ulmus, Zelkova - existent, as it seems, in al the three points.

\section{c. Late Sarmatian flora from Păun / laşi}

Păun village is located close to the town of laşi. The plants are extracted from a succession of gritstones and sands that are cropping out in the hill "La Catarg". They are well-dated by the presence of some mammal remains: Aceratherium incisivum Kaup., Hipparion sarmaticum Lungu and Ictitherium hipparionum Gervalis. The plants appear in the form of impressions on gritstone, an improper material for conservation and an exact identification. A big part of them appear as fragments, which denotes a torrential contribution, and which question the identifications made by Macarovici and Paghida (1966). We consider acceptable the following:

Daphnogene sp.

Liquidambar europaea Al. Br.

Platanus platanifolia (Ung.) Kn.

Ulmus pyramidalis Goepp.

Cassiophyllum berenives (Ung.) Kv.

Sapindus falcifolius Al. Br.

Salix varians Goepp.

Populus populina (Ung.) Kn.

Tilia cf. grandidentata lacub.

In this modest tafocenosis (of only 9 types) we find, on one hand, types already mentioned in Middle Sarmatian floras, on the other hand, some interesting news: Cassiophyllum, Sapindus, Tilia cf. grandidentata - a rarity like the Tilia leaves in the Romanian Tertiary, but most of all an unquestionable remnant of Daphnogene, the second Lauraceum from the Sarmatian of Moldavia. The vegetation brought probably from close vicinity is the one of a river meadow, except for Tilia, Sapindus and Cassiophyllum, probably Platanus. This vegetation shows that during the entire Sarmatian in the whole area considered, there was a uniform mesophytic vegetation, which shows very little variation depending on the possibilities of preservation in the deposit. We must also underline a problem, namely the absence of the Lauraceae. As we indicated, from the entire Sarmatian only two Lauraceae have been cited, Persea and Daphnogene. 
CONTRIBUTIONS TO THE KNOWLEDGE OF FLORA AND VEGETATION OF THE TERTIARY ...

Tab. 4.

The conspectus of the Sarmatian flora from Moldavia

\begin{tabular}{|c|c|c|c|c|c|c|c|c|c|c|}
\hline Name of the taxon & 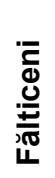 & 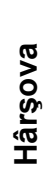 & 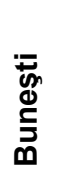 & 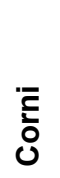 & 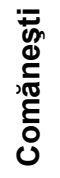 & $\underset{\substack{\mathfrak{\pi} \\
0}}{5}$ & 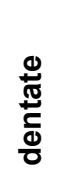 & 竞 & 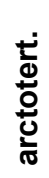 & 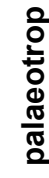 \\
\hline Acer ezoanum Oishi et Huzioka & & & & & + & & + & & + & \\
\hline Alnus cecropiaefolia (Ett.) / Berger & & & & & + & & + & & + & \\
\hline Alnus gaudini (Heer) Kn. et Kv. & + & & & & & & + & & + & \\
\hline Alnus kefersteini Ung. & & & & & + & & + & & + & \\
\hline Alnus latior Sap. & & & & & + & & + & & + & \\
\hline Berberis sp. & & & & + & & & + & & & + \\
\hline Betula oxydonta Sap. & + & & & & + & & + & & + & \\
\hline Betula prisca Ett. & & & & & + & & + & & + & \\
\hline Byttneriophyllum tiliaefolium & & & & & + & & & + & & + \\
\hline Carpinus grandis Ung. & + & + & + & + & + & & + & & + & \\
\hline Carpinus pyramidalis Heer & & + & & & & & & & & \\
\hline Carya serraefolia (Goepp.) Kr. & & & & + & & & + & & + & \\
\hline Cassiophyllum berenices (Ung.) Kr. & & & & & & + & & + & & + \\
\hline cf. Persea princeps (Heer) Schimp. & & + & & & & & & + & & + \\
\hline Corylus mac-quarrii Heer & + & & + & & & & + & & + & \\
\hline Daphnogene sp. & & & & & & + & & + & & + \\
\hline Fagus silesiaca Walt. et Zast. & & & & + & + & & + & & + & \\
\hline Fraxinus cf. excelsior L. & & & + & & & & + & & + & \\
\hline Glyptostrobus europaeus (Brngt.) & & & & & + & & & & & \\
\hline Juglans acuminata Al. Br.? & & + & & & & & + & & + & \\
\hline Leguminosites sp. & & + & & & & & & + & & + \\
\hline Liquidambar europaea Al. Br. & & & & + & & + & + & & + & \\
\hline Osmunda cf. regalis L. & + & & & & & & & & & \\
\hline Osmunda parschlugiana (Ung.) & & & & & + & & & & & \\
\hline Parrotia pristina (Ett.) Stur & & & & + & & & + & & + & \\
\hline Phragmites oeningensis Al. Br. & & & & & + & & & & & \\
\hline Platanus leucophylla (Ung.) Kn. & & + & & & & + & + & & + & \\
\hline Populus attenuata Al. Br. & & + & & & & & + & & + & \\
\hline Populus populina (Ung.) Kn. & & + & & & & + & + & & + & \\
\hline Potamogeton sp. & & & & & + & & & + & + & \\
\hline Quercus pseudorobur Goepp. & & & & + & & & + & & + & \\
\hline Quercus robur pliocaenica Sap. & & & + & & & & + & & + & \\
\hline Rhus cf. pyrrae Ung. & & + & & & & & + & & + & \\
\hline Salix varians Goepp. & & & & + & & + & + & & + & \\
\hline Sapindus falcifolius Al. Br. & & & & & & + & & + & & + \\
\hline Tilia cf. grandidentata lakub. & & & & & & + & + & & + & \\
\hline Ulmus pyramidalis Goepp. & & & + & + & & + & + & & + & \\
\hline Zelkova zelkovaefolia (Ung.) & & & + & + & & & + & & + & \\
\hline
\end{tabular}




\section{Conclusions on the Sarmatian floras}

Due to the fact that the Sarmatian flora is the only one well represented in the two geographical units considered, we will refer only to it. Its essential feature is that it includes the entire Sarmatian, as compared to the one from Transilvania, which refers only to the Early Sarmatian, and possibly Middle Sarmatian. Another specific feature that we mention here is its scarcity: the one from the south of the Carpathians contains 45 taxa, the one from the east - also contains 45 . But these figures compared to that of Transylvania, of 144 types, represent a minimum. In truth, as compared to the great number of types, and to the variety of those cited in Transylvania, the floras of the two geographical areas outside the Carpathians provide a minimum, which allows us to acknowledge the existence of a vegetation, without making it possible to characterize it from various points of view, as we did with the flora from inside the Carpathian arch (Givulescu 1992). Being compared between them the three floras show a particularly interesting fact: the flora from the south of the Carpathians is an extract from the flora from Transylvania. There are no significant differences between them. The flora from the east of the Carpathians is fundamentally different from the one in the other two areas mentioned, the essential difference consisting in the total absence of the Lauraceae (only Persea and Daphnogene with a single specimen each) and with a massive predominance of Betulaceae. We find the same situation in the rich and well-studied Sarmatian flora from Bursuc (Republic of Moldavia) (Givulescu 1999). Yet this one as well as those from west Moldavia abounds in remains of Carpinus and Quercus. It is obvious that in the east of the Carpathians we find another climate and, especially, that another palaeofitogeographic province is outlined, characterized, in the first place, by the absence of Lauraceae, good climate indicators. We suggest for this subprovince the name of "Moldavica", following that a more extended discussion is to be published on another occasion.

\section{REFERENCES}

Barbu, I. Z. (1933), Flora fosilă de la Timişani, jud.Gorjiu. Notat. Biol. 1, 2: 37-53.

Barbu, I. Z. (1934), Contribuții la cunoaşterea florei fosile din Podişul Moldovei. Acad. Rom. Mem. secț. şt., s. 3, 10, 4: 105-134.

Barbu, I. Z. (1936), Flora fosilă de la Muereasca de Sus județul Vîlcea. Acad. Rom. Mem. secț. şt. III, 11: 363-384.

Barbu, I. Z. (1942), Note sur les plantes fossiles du Miocene de Slătioara, département de Villcea. Bul. Soc. Rom. Geol. 5: 120-139.

Barbu, I. Z. (1954), Flora fosilă din Terțiarul Olteniei. An. Com. Geol. 27: 5-76.

Ciocîrdel, R. (1943), Neue Daten für das Alter des Beckens von Comăneşti. Mon. petr. rom. $44,1-2$. 


\section{CONTRIBUTIONS TO THE KNOWLEDGE OF FLORA AND VEGETATION OF THE TERTIARY ...}

Givulescu, R. (1963), Acer ezoanum Oishi et Huzioka în Miocenul din R.P.R. Comun. Acad. R.P.R. 13, 5: 445-448.

Givulescu, R. (1968) Date noi privind flora fosilă a Bazinului Comăneşti. Studii şi cerc. S. geol. 13, I: 285-288.

Givulescu, R. (1971), Asupra unor plante fosile din colecțiile Institutului Geologic din Bucureşti. D. S. Inst. Geol. 57, 3: 115-124.

Givulescu, R. (1971), Le genre Buxus dans le Tertiaire de la Roumanie et brèves considérations sur la repartition du genre à l'état fossile en Europe. Bull. mens. soc. Linnéenne 40, 8: 251-256.

Givulescu, R. (1989), Laurophyllum paucae n. sp. a Lauraceous with preserved epidermis from the Oligocene at Suslăneşti/Argeş/Romania. Olig. Trans. Bas. Sympos. 215-218.

Givulescu, R. (1989), Contributions to the knowledge of the Oligocene flora at Suslăneşti/Argeş district - Romania. Olig. Trans. Bas. Symp. 219-226.

Givulescu, R. (1992), O revizuire a lucrării lui I. Z. Barbu. Flora fosilă de la Muereasca de Sus, județul Vîlcea. Rom. J. Paleont., 75: 61-63.

Givulescu, R. (1992). Considerations on the sarmatian flora of Transilvania. Roman. J. Paleont. 75: 45-59.

Macarovici, N., Paghida, N. (1966), Flora şi fauna din Sarmațianul superior de la Păun/laşi. Anal. Univ. Bucureşti, şt. nat. (geol., geogr.), 15, 1: 67-81.

Marion, A.F., Laurent, L. (1898), Examen d'une colection de végétaux fossiles de Roumanie. An. Muz. Geol. Paleont.: 325-335.

Paucă, M. (1933), Die fossile Fauna und Flora aus dem Oligozän von Suslăneşti/Muscel in Rumänien. An. Inst. Geol. Rom. 16: 525-570.

Pauliuc S., Cioflică, G., Ticleanu, N. (1970), Plante fosile din Pliocenul depresiunii Soimari, județul Prahova. D. S. şed. Inst. Geol. 55, 3: 123-138.

Stancu, I., Ticleanu, N. (1975), Date noi privind flora Badenianului din România. D. S. şed. Inst. Geol. Geof. 61, 3: 185-203.

Ticleanu, N. (1970), Contribuții la cunoaşterea florei sarmațiene de la TănăşeştiRîmeşti, (Vîlcea). D. S. şed. Inst. Geol. 56: 67-75.

Țicleanu, N., Micu, M. (1978), Flore sarmatienne de Corni (District de Neamț). D. S. şed. Inst. Geol. Geof. 64, 3: 389-414.

Țicleanu, N., Huică, I., Țicleanu, M. (1979) Contributions à la connaissance de la flore pliocene de la Roumanie. La flore dacienne de Dedovița (District de Mehedinți). D. S. Inst. geol. geof., 66, 3: 127-143.

Țicleanu, N. (1984) Contributions to the study of the upper Badenian flora from Romania. D. S. şed. Inst. Geol. Geof. 68, 3: 135-150. 